\title{
PROBLEMATIKA PENEGAKAN HUKUM \\ DAN ETIKA PROFESI DI INDONESIA: Analisis dengan Pendekatan Nilai-nilai Ajaran Islam
}

\author{
Suhri Hanafi \\ STAIN Datokarama Palu, Jl. Diponegoro 23 Palu \\ e-mail: suhrihanafi@gmail.com
}

\section{Abstract}

This paper deals with the enforcement of the law and the ethical codes of legal profession, with an analysis from the Islamic approach. It explores legal issues that relate to legal officials, as well as the background and reasons behind the significance of such enforcement that is based on Islamic piety (taqwâ). This paper concludes that the enforcement of the ethical code of legal profession, which is based on Islamic piety, is a solution for the law enforcement and the establishment of the supremacy of law in society as well.

$$
\begin{aligned}
& \text { يتناول هذا الحث المشاكل فى تطبيق القانون و آداب وظيفة العمل فى }
\end{aligned}
$$

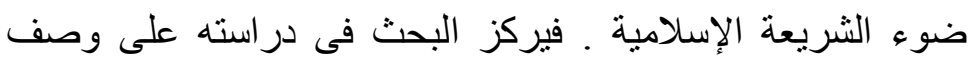



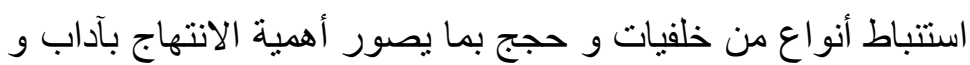

$$
\begin{aligned}
& \text { ظيفة العمل فى مجال القانون بناء على الإيمان بالهه سبحنه و تقو اه }
\end{aligned}
$$

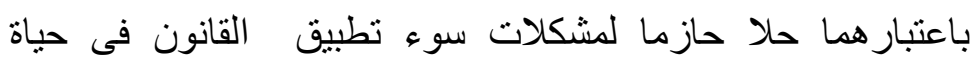

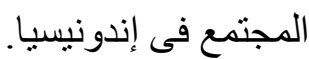

Kata Kunci: penegakan hukum, norma hukum, etika profesi, ajaran Islam 


\section{PENDAHULUAN}

Dalam kajian ilmu hukum dikemukakan bahwa selain norma hukum, terdapat juga norma lain yang turut menopang tegaknya ketertiban dalam masyarakat. Norma hukum tidaklah mampu secara mandiri menjangkau seluruh aspek kehidupan manusia. Oleh karena itu, diperlukan tatanan lain sebagai upaya mewujudkan ketertiban dalam masyarakat.

Sebagai konsekuensi logis dari kondisi tersebut, lahirlah norma etika dari berbagai kelompok profesi yang dirumuskan dalam bentuk kode etik profesi yang bertujuan untuk membina, melindungi serta mengawasi anggota kelompok profesinya. Demikian halnya dengan profesi hukum misalnya profesi advokat, notaris dan lain-lain yang kesemuanya telah merumuskan kode etiknya masing-masing. Lahirnya rumusan kode etik dari berbagai kelompok profesi tentunya dilatarbelakangi oleh banyak faktor yang intinya tidak maksimal dalam fungsi pelayanan.

Rahardjo (1996:14) mengemukakan bahwa tatanan dalam masyarakat yaitu yang menciptakan hubungan-hubungan yang tetap dan teratur antara anggota-anggota masyarakat sesungguhnya tidak merupakan suatu konsep yang tunggal. Akan tetapi, di dalam tatanan tersebut terdapat sub-sub tatanan, antara lain kebiasaan, hukum dan kesusilaan/moral. Inti dari sub tatanan kesusilaan/moral ini justru berpegang kepada ideal yang masih harus diwujudkan dalam masyarakat. Idelah yang merupakan tolok ukur tatanan ini untuk menilai tingkah laku anggota masyarakat. Dengan demikian, perbuatan yang dapat diterima oleh tatanan tersebut hanya yang sesuai dengan yang ideal tentang manusia.

Pandangan yang telah dikemukakan di atas sedikit berbeda dengan pandangan Islam. Dalam agama Islam tidak ada pemisahan yang tegas antara hukum dan etika. Islam memandang bahwa antara hukum dan etika adalah satu kesatuan yang tak terpisahkan dalam membentuk sebuah kehidupan yang sempurna. Baik etika maupun hukum merupakan nilai yang menopang tegaknya ketertiban dalam masyarakat. 


\section{PENGERTIAN ETIKA, MORAL, KESUSILAAN, DAN} AKHLAK

Terdapat beberapa istilah yang seringkali dipahami atau dimaknai sama dengan etika, yakni moral, akhlak, dan kesusilaan. Istilah tersebut biasanya dipakai secara bergantian untuk menunjukkan maksud yang sama oleh kebanyakan orang. Namun demikian, banyak pula ahli yang membedakan pengertian istilah tersebut antara satu dengan yang lain.

Dalam Kamus Besar Bahasa Indonesia (1994:271), etika diartikan sebagai ilmu tentang apa yang baik dan apa yang buruk dan tentang hak dan kewajiban moral (akhlak). Menurut Lubis (1994:1), perkataan etika berasal dari perkataan "ethos" sehingga muncul kata "etika". "Ethos" itu sendiri dapat diartikan sebagai kesusilaan, perasan bathin atau kecenderungan hati seseorang untuk berbuat kebaikan. Dalam istilah Latin, "ethos" atau "ethikos" selalu disebut dengan "mos" sehingga dari perkataan tersebut lahirlah "moralitas" atau yang sering diistilahkan dengan "moral".

Menurut Lubis (1994:1), apabila dibandingkan dalam pemakaian yang lebih luas, perkataan etika dipandang sebagai lebih luas dari perkataan moral, sebab terkadang istilah moral dipergunakan hanya untuk menerangkan sikap lahiriah seseorang yang biasanya dinilai dari wujud tingkah laku atau perbuatannya saja. Sedangkan etika dipandang selain menunjukkan sikap lahirilah seseorang, juga meliputi kaidah-kaidah dan motif-motif perbuatan seseorang. Namun demikian, ada pula yang menyamakan pengertian etika dengan moral seperti yang dikemukakan oleh Bartens dalam Supriadi (2004:12) bahwa kata yang sangat dekat dengan etika adalah moral. Secara etimologis, kata etika sama dengan kata moral. Perbedaannya hanya pada bahasa asalnya. Etika berasal dari bahasa Yunani, sedangkan moral berasal dari bahasa Latin.

Dalam Ensiklopedi Pendidikan seperti yang dikutip (Lubis, 1994:2) disebutkan bahwa etika adalah filsafat tentang nilai, kesulisaan, tentang baik dan buruk, kecuali etika mempelajari nilainilai, ia juga merupakan pengetahuan tentang nilai-nilai itu sendiri. 
Istilah etika bilamana dibandingkan dengan akhlak, menurut Lubis (1994:3), etika adalah bagian dari akhlak. Dikatakan demikian karena akhlak bukan sekedar menyangkut perilaku manusia yang bersifat perbuatan lahiriah, tetapi juga mencakup hal-hal yang lebih luas, yaitu meliputi bidang akidah, ibadah, dan syariah. Oleh karena itu, akhlak islami cakupannya sangat luas, yaitu menyangkut:

- etos yang mengatur hubungan seseorang dengan Penciptanya, alma'bûd bi al-h $\square a q$ serta kelengkapan ulûhyiyah dan rubûbyiyah, seperti terhadap rasul-rasul Allah, kitab-kitab-Nya dan sebagainya;

- $\quad$ etis yang mengatur sikap seseorang terhadap dirinya dan terhadap sesamanya dalam kegiatan kehidupan sehari-hari;

- moral; yang mengatur hubungan dengan sesamanya, tetapi berlainan jenis dan atau yang menyangkut kehormatan tiap pribadi;

- estetika, yaitu rasa keindahan yang mendorong seseorag untuk meningkatkan keadaan dirinya serta lingkungannya, agar lebih indah dan menuju kesempurnaan.

Definisi akhlak dapat juga dilihat misalnya dari pengertian akhlak yang dikemukakan oleh Syahidin dkk. (2004:76) bahwa secara terminologis, akhlak adalah ilmu yang menentukan batas antara yang baik dan buruk, terpuji dan tercela, menyangkut perkataan dan perbuatan manusia lahir batin. Secara rinci kajian akhlak itu meliputi:

- $\quad$ pengertian baik dan buruk;

- menerangkan apa yang harus dilakukan oleh seorang manusia terhadap manusia lainnya;

- menjelaskan tujuan yang seharusnya dicapai oleh manusia dengan perbuatan-perbuatannya;

- menerangkan jalan yang harus dilalui untuk berbuat.

Selanjutnya Syahidin dkk. (2004:78) mengemukakan pendapat Ibnu Miskawayh dan Al-Ghazâlî tentang akhlak. Menurut Ibnu Miskawayh akhlak adalah keadaan jiwa seseorang yang mendorongnya untuk melakukan perbuatan-perbuatan tanpa melalui pertimbangan pikiran terlebih dahulu. Sedangkan Al-Ghazâlî menyebutkan bahwa akhlak adalah suatu sifat yang tertanam dalam 
jiwa yang daripadanya timbul perbuatan-perbuatan dengan mudah tanpa memerlukan pertimbangan pikiran.

Dua definisi yang dikemukakan di atas menggambarkan bahwa akhlak secara substansial adalah sifat hati (kondisi hati), bisa baik dan bisa pula buruk yang tercermin dalam perilaku. Jika hatinya baik maka yang muncul adalah akhlak yang baik (akhlâq al-karîmah) dan jika hatinya buruk maka yang tampak dari perilakunya adalah akhlak yang buruk pula (akhlâq al-maz $\square$ mûmah).

Beragamanya pengertian tentang etika sebagaimana telah dikemukakan di atas, terdapat satu hal penting dan merupakan benang merah dari seluruh pengertian tersebut, yaitu seluruh pengertian yang dikemukakan mengandung makna bahwa etika adalah pengetahuan yang mengajarkan dan mendorong manusia kepada kebaikan, kemudian juga menunjukkan tentang hal-hal buruk dan mengajak manusia untuk menjauhinya.

\section{PENGERTIAN PROFESI DAN RUANG LINGKUP PROFESI HUKUM}

\section{Pengertian Profesi}

Menurut Ali (1998:333), kita sering mendengar orang yang menyatakan bahwa profesi si "Baco" adalah tukang becak. Pernyataan tersebut adalah keliru karena tukang becak bukanlah sebuah profesi, tetapi hanya salah satu jenis pekerjaan, meskipun semua profesi termasuk pekerjaan. Secara etimologis, sebagaimana dikemukakan dalam Kamus Besar Bahasa Indonesia (1994:261) profesi adalah bidang pekerjaan yang dilandasi keahlian (keterampilan, kejuruan), dan sebagainya.

Lebih lanjut, Ali (1998:335) merumuskan unsur-unsur yang seyogianya terdapat dalam profesi yaitu:

- merupakan pekerjaan atau lapangan kerja khusus yang hanya mungkin dicapai dengan pendidikan dan latihan khusus;

- keahliannya didasarkan pada pengetahuan teoritis, namun dalam penerapannya apakah gemilang atau biasa-biasa saja sangat tergantung pada kemampuan person dari tenaga professional tersebut. 
- mendapat pengakuan masyarakat dengan persyaratan bahwa untuk diterima menggeluti profesi itu dibutuhkan suatu tes atau ujian formal yang tingkatannya bertaraf advanced (lanjutan);

yang diandalkan bukan sekedar kemampuan yang bersifat fisik dan kasar (manual), tetapi kemampuan intelek tingkat tinggi;

- kemampuan itu ditujukan sebagai pelayanan umum yang tergolong dalam altruistic service (pelayanan yang lebih mementingkan kepentingan orang lain).

- adanya organisasi atau asosiasi profesi tersebut, dengan etika profesi yang jelas.

Selain unsur-unsur profesi sebagaimana dikemukakan di atas, masih banyak pendapat yang menguraikan atau menjelaskan unsurunsur yang harus dipenuhi oleh sebuah profesi. Saputro (1991:27) mengemukakan bahwa agar suatu lapangan kerja dapat dikategorikan sebagai profesi, diperlukan:

- pengetahuan;

- penerapan keahlian (competence of application);

- tanggung jawab sosial (social responsibility);

- pengawasan diri (self control);

- pengakuan oleh masyarakat.

\section{Ruang Lingkup Profesi Hukum}

Ali (1998: 338) membagi kategori profesi hukum menjadi 2 yaitu: profesi hukum konvensional dan profesi hukum modern.

Profesi hukum yang dikategorikan sebagai profesi hukum konvensional adalah antara lain:

- Hakim adalah pejabat yang melakukan kekuasaan kehakiman yang diatur dengan undang-undang. (UU No. 4 Tahun 2004)

- Jaksa adalah pejabat fungsional yang diberi wewenang oleh Undang-undang untuk bertindak sebagai penuntut umum dan pelaksana putusan pengadilan yang telah memperoleh kekuatan hukum tetap serta wewenang lain berdasarkan undang-undang. (UU No. 16 Tahun 2004)

- Pengacara (advokat) adalah orang yang berprofesi memberi jasa hukum, baik dalam maupun di luar pengadilan yang memenuhi 
persyaratan berdasarkan ketentuan undang-undang. (UU No. 18/2003)

- Kepolisian adalah Kepolisian Negara Republik Indonesia yang merupakan alat negara yang berperan dalam memelihara keamanan dan ketertiban masyarakat, menegakkan hukum, serta memberikan perlindungan, pengayoman dan pelayanan kepada masyarakat.(UU No.2 Tahun 2002)

- Notaris adalah pejabat umum yang berwenang untuk membuat akta autentik dan kewenangan lainnya sebaimana dimaksud dalam UU No. 30/2004 tentang Jabatan Notaris

- Ilmuan hukum yang dimaksud di sini adalah termasuk dosen ilmu hukum.

Sedangkan profesi hukum yang dikategorikan sebagai profesi hukum modern adalah profesi hukum yang baru muncul dalam abad ke-20 antara lain Konsultan Hukum yang tidak tampil ke pengadilan melainkan hanya menjadi advisor bagi perusahaan-perusahaan, pejabat Pemerintah yang bertugas di bagian hukum yang ada dalam badan Pemerintah.

Selain itu, sebuah profesi hukum yang belum banyak dikenal masyarakat adalah kurator. Keberadaan profesi hukum ini (kurator) ditegaskan dalam Undang-Undang Nomor 37 Tahun 2004 tentang Kepailitan dan Penundaan Kewajiban Pembayaran Utang (PKPU), masyarakat kurang mengenal dunia kurator, termasuk di dalamnya mungkin sebagian dari para penegak hukum itu sendiri.

\section{PROFESI HUKUM DAN PERMASALAHANNYA}

Menurut Supriadi (2006:21-22) ada lima masalah yang dihadapi sebagai kendala yang cukup serius bagi profesi hukum yaitu:

Pertama, kualitas pengetahuan profesional hukum Seorang profesional hukum harus memiliki pengetahuan bidang hukum yang andal, sebagai penentu bobot kualitas pelayanan hukum secara profesional kepada masyarakat. Hal ini sesuai pasal 1 Keputusan Mendikbud No. 17/Kep./O/1992 tentang Kurikulum Nasional Bidang Hukum, Program Pendidikan Sarjana Hukum bertujuan untuk menghasilkan sarjana hukum yang: 
- menguasai hukum Indonesia;

- mampu menganalisis masalah hukum dalam masyarakat;

- mampu menggunakan hukum sebagai sarana untuk memecahkan masalah konkret dengan bijaksana dan tetap berdasarkan prinsipprinsip hukum;

- menguasai dasar ilmiah untuk mengembangkan ilmu hukum dan hukum;

- mengenal dan peka terhadap masalah keadilan dan masalah sosial.

Kedua, terjadi penyalahgunaan profesi. Dalam kenyataannya, di tengah-tengah masyarakat seringkali terjadi penyalahgunaan profesi hukum oleh anggotanya sendiri. Terjadinya penyalahgunaan profesi tersebut disebabkan adanya factor kepentingan. Persaingan individu profesional hukum serta tidak adanya disiplin diri menjadi pemicu terjadinya penyalahgunaan ini. Dalam dunia profesi hukum dapat dilihat dua hal yang sering kontradiksi satu sama lain yaitu pada satu sisi, cita-cita etika yang terlalu tinggi, sementara pada sisi lainnya praktik penggembalaan hukum yang berada jauh di bawah cita-cita tersebut. Selain itu, penyalahgunaan profesi hukum juga terjadi karena desakan pihak klien yang menginginkan perkaranya cepat selesai dan tentunya memperoleh kemenangan. Klien kadangkala tidak segansegan menawarkan bayaran yang menggiurkan kepada pihak tertentu untuk memperoleh kemenangan.

Ketiga, kecenderungan profesi hukum menjadi kegiatan bisnis. Suatu fakta yang tidak dapat dipungkiri bahwa sebenarnya kehadiran profesi hukum bertujuan untuk memberikan pelayanan atau memberikan bantuan hukum kepada masyarakat. Dalam artian bahwa yang terpenting adalah pelayanan dan pengabdian. Namun dalam kenyataannya di Indonesia, profesi hukum dapat dibedakan antara profesi hukum yang bergerak dalam bidang pelayanan bisnis dan profesi hukum di bidang pelayanan umum. Profesi hukum yang bergerak dalam bidang pelayanan bisnis menjalankan pekerjaan berdasarkan hubungan bisnis (komersial), imbalan yang diterima sudah ditentukan menurut standar bisnis. Contohnya, para konsultan yang menangani masalah kontrak-kontrak dagang, paten, dan merek. Untuk profesi hukum yang bergerak di bidang pelayanan umum menjalankan pekerjaan berdasarkan kepentingan umum, baik dengan 
pembayaran maupun tanpa pembayaran. Contoh profesi hukum pelayanan umum adalah pengadilan, notaris, LBH, jika ada pembayaran, sifatnya biaya pekerjaan atau biaya administrasi.

Keempat, penurunan kesadaran dan kepedulian sosial. Kesadaran dan kepedulian sosial merupakan kriteria pelayanan umum profesional hukum. Wujudnya adalah kepentingan masyarakat lebih diutamakan atau didahulukan daripada kepentingan pribadi, pelayanan lebih diutamakan daripada pembayaran, nilai moral ditonjolkan daripada nilai ekonomi. Namun demikian, gejala yang dapat diamati sekarang sepertinya lain dari yang seharusnya diemban oleh profesional hukum. Gejala tersebut menunjukkan mulai pudarnya keyakinan terhadap wibawa hukum.

Kelima, kontinuitas sistem yang sudah usang. Profesional hukum adalah bagian dari sistem peradilan yang berperan membantu menyebarluaskan sistem yang sudah dianggap ketinggalan zaman karena di dalamnya terdapat banyak ketentuan penegakan hukum yang tidak lagi sesuai. Padahal profesional hukum melayani kepentingan masyarakat yang hidup dalam zaman modern. Kemajuan teknologi sekarang kurang diimbangi oleh percepatan kemajuan hukum yang dapat menangkal kemajuan teknologi tersebut sehingga timbul hukum selalu ketinggalan zaman.

Dari berbagai permasalahan kronis yang dihadapi oleh para profesional hukum sebagaimana telah dikemukakan di atas, rumusan kode etik para kelompok profesional hukum diharapkan mampu menjadi solusi bagi permasalahan tersebut. Namun demikian, hal yang terpenting adalah bahwa setiap anggota profesi hukum selayaknya memiliki akhlak yang mulia sebagai bekal utama dalam menjalankan amanah yang dipercayakan kepadanya. Meskipun di dalam kode etik telah terdapat unsur pembinaan terutama berupa pembinaan yang dilakukan oleh organisasi, senior, dan teman sejawat, namun menurut hemat penulis, hal itu belumlah cukup. Masih perlu pembekalan secara mendalam terutama menyangkut penghayatan dan pengamalan nilai-nilai ajaran agama.

Sebagai tindak lanjut dari upaya menanamkan nilai-nilai etika bagi para profesional hukum, maka lahirlah kesepakatan oleh dekan Fakultas Hukum se-Indonesia, untuk memasukkan mata kuliah etika 
profesi hukum sebagai materi perkuliahan. Hal ini diharapkan untuk membina secara dini calon-calon profesional di bidang hukum. Dengan adanya pelajaran etika pada tingkat perguruan tinggi hukum, harapan yang paling utama adalah lahirnya sarjana-sarjana hukum/sarjana syariah yang memiliki kepribadian dan etika/akhlak mulia dalam menjalankan aktivitasnya.

Seorang pengembang profesi hukum harus menjadi orang yang dapat dipercaya atau amanah. Amanah merupakan syarat mutlak bagi seorang anggota profesi. Inilah salah satu faktor mengapa etika/akhlak sangat diperlukan dalam dunia profesi.

Lubis (1994:6) mengemukakan bahwa hubungan etika dengan profesi hukum adalah bahwa etika profesi adalah sebagai sikap hidup, hal mana bisa berarti kesediaan untuk memberikan pelayanan professional di bidang hukum terhadap masyarakat dengan keterlibatan penuh dan keahlian sebagai pelayanan dalam melaksanakan tugas yang berupa kewajiban terhadap masyarakat yang membutuhkan pelayanan hukum disertai refleksi yang seksama, dan oleh karena itu di dalam melaksanakan profesi terdapat kaidah-kaidah pokok berupa etika profesi sebagai dikemukakan oleh Kieser dalam Lubis (1994:7), yaitu:

Pertama, profesi harus dipandang dan dihayati sebagai suatu pelayanan, karena itu maka sifat tanpa pamrih menjadi ciri khas dalam mengembangkan profesi. Yang dimaksud dengan tanpa pamrih di sini adalah bahwa pertimbangan yang menentukan dalam pengambilan keputusan adalah kepentingan pasien atau klien dan kepentingan umum, dan bukan kepentingan pribadi. Jika sifat tanpa pamrih ini diabaikan, maka pengembangan profesi akan mengarah pada pemanfaatan (yang menjurus kepada penyalahgunaan) kewenangan terhadap sesama manusia yang sedang mengalami kesulitan.

Kedua, pelayanan profesional dalam mendahulukan kepentingan pasien atau klien mengacu kepada kepentingan atau nilai-nilai luhur sebagai norma kritik yang memotivasi sikap dan tindakan.

Ketiga, pengembangan profesi harus selalu berorientasi pada masyarakat sebagai keseluruhan.

Keempat, agar persaingan dalam pelayanan berlangsung secara sehat sehingga dapat menjamin mutu dan peningkatan mutu 
pengemban profesi, maka pengembangan profesi harus bersemangat solidaritas antar sesame rekan seprofesi.

\section{KODE ETIK PROFESI HUKUM}

Etika profesi adalah sebuah norma yang dituangkan dalam satu bentuk peraturan yang lazim diistilahkan dengan kode etik profesi. Kode etik profesi ini sepatutnya menjadi landasan bagi seorang profesional dalam mengembang profesinya. Hingga saat ini, hampir seluruh kelompok organisasi profesi telah memiliki kode etik masingmasing, misalnya kode etik kedokteran, kode etik jurnalistik, Demikian juga profesi hukum,. seluruhnya telah memiliki kode etik masing-masing. Misalnya, kode etik notaris, kode etik advokat dan hakim, dan lain-lain. Untuk menegakkan etika dalam dunia profesi, lazimnya prinsip-prinsip yang wajib ditegakkan oleh suatu kelompok profesi harus dirumuskan ke dalam suatu kode etik. Dengan demikian, cita-cita luhur yang hendak dicapai oleh suatu kelompok profesi merupakan kemupakatan secara umum oleh seluruh anggota profesi tersebut.

Menurut Kansil dan Christine (2003:6), di Indonesia kode etik suatu profesi biasanya disusun oleh wakil-wakil yang duduk dalam asosialsi profesi itu sendiri. Kesulitan akan timbul apabila untuk satu macam profesi terdapat lebih dari satu asosiasi. Kesulitan lain akan timbul jika prinsif-prinsif profesi diterjemahkan secara berbeda dalam kode etik mereka.

Salah satu contoh kendala sebagai telah dikemukakan di atas, misalnya organisasi kepengacaraan yang ada saat ini belum mampu diwadahi oleh satu organisasi induk. Keadaan ini telah berlangsung sejak lama sebelum hingga lahirnya Undang-Undang tentang Advokat. Kondisi ini masih terus berlanjut. Organisasi PERADI yang dibentuk oleh para advokat seolah-olah belum mampu menjadi wadah tunggal dalam mengakomodir seluruh aspirasi advokat yang ada di Indonesia.

Demikian juga halnya dengan para notaris. Mereka juga telah memiliki lebih dari satu organisasi profesi, padahal Undang-Undang tentang Jabatan Notaris menghendaki hanya ada satu organisasi profesi notaris. Meskipun hal ini telah diklaim oleh Ikatan Notaris 
Indonesia (INI) bahwa saat ini semua notaris harus bergabung dalam organisasi ini.

\section{NILAI-NILAI DASAR ISLAM DAN UPAYA MEWUJUDKAN KETERTIBAN MASYARAKAT}

Seluruh ajaran Islam yang tertuang dalam Alquran dan hadis, pada dasarnya bermuara pada takwa. Konsep takwa ini adalah bagaimana membentuk manusia menjadi manusia paripurna. Hal ini sangat jelas disebutkan dalam Alquran surat Al-Hujurât (49): 13 sebagai berkut:

Terjemahnya:

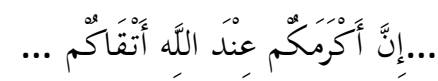

...sesungguhnya orang yang paling mulia di antara kamu di sisi Allah ialah orang yang paling bertakwa di antara kamu...

Takwa adalah sebuah kondisi yang menuntun manusia melakukan hal-hal terpuji, jujur, amanah dan lain-lain serta menjauhkan manusia dari sifat tercela.

Banyaknya masalah di bidang hukum sebagaimana dikemukakan pada pembahasan di atas, sangat terkait dengan menurunnya atau kurangnya nilai takwa dalam diri seseorang, termasuk juga penegak hukum. Dengan demikian, konsep takwa yang ditawarkan Islam adalah sebuah solusi yang dapat digunakan untuk menghindari keterpurukan hukum yang selama ini mendera bangsa Indonesia.

Penegakan hukum maupun kode etik profesi hukum yang tidak dilandasi dengan takwa hanya akan menjadi bias, bahkan celah hukum dan kode etik profesi justru menjadi tempat berlindung bagi profesional hukum yang tidak bertanggung jawab.

Secara singkat, refleksi ketakwaan yang terdapat dalam diri manusia selalu mengarah setidaknya pada tiga aspek yaitu akhlak alkarîmah, uswatun $h \square$ asanah dan rah $\square$ matun li al-'âlamîn.

Akhlak sebagai salah satu refleksi ketakwaan sebagaimana dikemukakan di atas, juga merupakan salah satu misi kerasulan Muhammad saw. Hal ini dipertegas dengan sebuah hadis nabi bahwa sesungguhnya ia diutus untuk menyempurnakan akhlak umat manusia. 
Aspek yang kedua adalah keteladanan. penegakan hukum maupun penegakan kode etik profesi bagi para penegak hukum akan menjadi cermin bagi masyarakat dalam menegakkan hukum. Hukum akan semakin terpuruk jika para penegak hukum tidak mampu menjadi teladan dalam penegakan hukum itu sendiri.

Aspek yang ketiga adalah sebagai rah $\square$ matun li al-'âlamîn. Dengan memiliki akhlak mulia dan keteladanan, di mana pun berada, seorang penegak hukum akan memberi manfaat bagi lingkungan sosialnya.

\section{PENUTUP}

Berdasarkan uraian di atas, dapat disimpulkan bahwa penegakan hukum telah mengalami keterpurukan yang ditandai dengan banyaknya permasalahan hukum. Dengan demikian, harus dilakukan berbagai upaya untuk mewujudkan penegakan hukum yang harus dimulai dari para profesional hukum, terutama hakim, jaksa, pengarcara, polisi dan lain-lain.

Salah satu jalan yang telah ditempuh sebagai upaya penegakan hukum adalah penegakan etika (kode etik) yang dilandasi oleh nilainilai ajaran Islam bagi profesional hukum. Dengan demikian, penegakan kode etik profesi menjadi mutlak adanya bagi tiap-tiap pribadi profesional hukum.

\section{DAFTAR PUSTAKA}

Ali, Achmad. 1998. Menjelajahi Kajian Empiris terhadap Hukum. Jakarta: Yasrif Watampone.

Departemen Agama RI. 2009. Al-Qur'an dan Terjemahnya. Jakarta: Yayasan Penyelenggara/Penafsir al-Qur'an

Departemen Pendidikan dan Kebudayaan.1994. Kamus Besar Bahasa Indonesia. Jakarta: Balai Pustaka.

Kansil \& Christine. 2003. Pokok-Pokok Etika Profesi Hukum. Jakarta: Pradnya Paramita.

Lubis, Suhrawardi K. 1994. Etika Profesi Hukum. Jakarta: Sinar Grafika.

Rahardjo, Satjipto. 1996. Ilmu Hukum. Bandung: Rineka Cipta.

Saputro, Liliana Tedjo. 1991. Etika Profesi dan Profesi Hukum. Semarang: Aneka Ilmu. 
Jurnal Hunafa, Vol. 6, No.2, Agustus 2009:233-246

Supriadi. 2006. Etika dan Tanggung Jawab Profesi Hukum di Indonesia. Jakarta: Sinar Grafika.

Syahidin, dkk. 2004 Materi Insrtuksional Pendidikan Agama Islam di Perguruan Tinggi Umum. Jakarta: Direktorat Perguruan Tinggi Agama Departemen Agama RI. 